Article

\title{
Biomechanical Properties and Agro-Morphological Traits for Improved Lodging Resistance in Ethiopian Teff (Eragrostis tef (Zucc.) Trottor) Accessions
}

\author{
Muluken Bayable ${ }^{1,2, *}$, Atsushi Tsunekawa ${ }^{3}{ }^{\mathbb{D}}$, Nigussie Haregeweyn ${ }^{4}\left(\mathbb{D}\right.$, Takayoshi Ishii $^{3}$, \\ Getachew Alemayehu ${ }^{5}$, Mitsuru Tsubo ${ }^{3}$, Enyew Adgo ${ }^{5}{ }^{\mathbb{D}}$, Asaminew Tassew ${ }^{5}$, Wataru Tsuji ${ }^{6}$, \\ Fekremariam Asaregew ${ }^{1,2}$ (D) and Tsugiyuki Masunaga ${ }^{7}$ \\ 1 United Graduate School of Agricultural Sciences, Tottori University, 4-101 Koyama-Minami, \\ Tottori 680-8553, Japan; fikruas2005@gmail.com \\ 2 Amhara Regional Agricultural Research Institute, P.O. Box 527, Bahir Dar, Ethiopia \\ 3 Arid Land Research Center, Tottori University, 1390 Hamasaka, Tottori 680-0001, Japan; \\ tsunekawa@tottori-u.ac.jp (A.T.); Ishii.T@tottori-u.ac.jp (T.I.); tsubo@tottori-u.ac.jp (M.T.) \\ 4 International Platform for Dryland Research and Education, Tottori University, Tottori 680-0001, Japan; \\ nigussie_haregeweyn@yahoo.com \\ 5 College of Agriculture and Environmental Sciences, Bahir Dar University, P.O. Box 1289, Bahir Dar, Ethiopia; \\ getachew64@gmail.com (G.A.); enyewadgo@gmail.com (E.A.); asaminew2@gmail.com (A.T.) \\ 6 Faculty of Agriculture, Tottori University, 4-101 Koyama-Minami, Tottori 680-8553, Japan; \\ w.tsuji@tottori-u.ac.jp \\ 7 Faculty of Life and Environmental Sciences, Shimane University, Shimane, Matsue 690-0823, Japan; \\ masunaga@life.shimane-u.ac.jp \\ * Correspondence: mulukenbaya2010@gmail.com
}

Received: 10 June 2020; Accepted: 12 July 2020; Published: 14 July 2020

check for updates

\begin{abstract}
Susceptibility to lodging is a major constraint on teff production in Ethiopia, but efforts to develop lodging-resistant cultivars have not been successful. We studied the mechanical properties of teff culms and associated agro-morphological traits in field experiments with 320 teff accessions at two sites in northwestern Ethiopia during the 2018 and 2019 growing seasons. The results showed significant variability in both mechanical properties and agro-morphological traits among accessions. Traits contributing to lodging resistance, such as internode diameter, pushing resistance, and base failure moment, were significantly positively correlated with each other and with plant height. Similarly, the correlation of those traits with lodging index was significant and positive. In contrast, tiller number showed a significant negative correlation with lodging index. The peduncle-panicle length, which generally accounted for $59 \%$ of the plant height, should be a target when breeding for semi-dwarfism. Root system development, which reached a depth of more than $1 \mathrm{~m}$ in tall and $57 \mathrm{~cm}$ in dwarf teff accessions, signifies the presence of genetic variabilities for future root lodging studies in teff, and it may also explain why teff performs well in drought-prone areas of Ethiopia. Breeding programs for lodging resistance might focus on accessions with good standing ability (high base failure moment) and introgression of stem strength with a semi-dwarf phenotype. Alternatively, selection for a large internode diameter, increased pushing resistance and base failure moment, and a reduced tiller number should be considered.
\end{abstract}

Keywords: base failure moment; breeding; lodging; plant height; pushing resistance; teff

\section{Introduction}

Teff (Eragrostis tef (Zucc.) Trottor) is a traditional, culturally important indigenous cereal food crop in Ethiopia, where it is eaten by half of the population at least once a day [1-3]. Besides its nutritional 
importance, teff is known for its ability to adapt to extreme conditions, including in areas prone to waterlogging or drought, where most cereal crops might fail. In Ethiopia, where $67 \%$ of the total area is regarded as dryland and climate variability affects crop production [4], teff continues to be the main economic crop of small-scale farmers. Teff has been cultivated in some parts of the world for livestock feed since the Royal Botanical Garden, Kew, distributed it in the late 19th century from Ethiopia [5,6], its place of origin and the center of diversity. In Ethiopia, however, it has been cultivated for human food for centuries $[7,8]$. Today, as a result of the Ethiopian diaspora in different parts of the world and because it is both nutritious and gluten free, other consumers have become interested in teff. As a result, it has become an important agricultural commodity for export in Ethiopia [9]. The increased export demand coupled with low crop productivity, however, has raised the market price of teff beyond the purchasing capacity of local consumers. Consequently, the Ethiopian government was forced to temporarily suspend the export of teff in 2006. This situation has led to the realization that, unless there is a significant productivity boost, teff will cease to be the staple food of many Ethiopians.

The average nationwide teff yield in Ethiopia is only about $1.76 \mathrm{t} / \mathrm{ha}$ [10], but it has been estimated that if lodging can be prevented, the yield might rise to $4.6 \mathrm{t} / \mathrm{ha}[11,12]$. Lodging, i.e., the irreversible displacement of a plant stem from its vertical due to a weak culm and/or to poor root system anchorage, which can be aggravated by winds, rain, or hail [13], is a major factor limiting yield and quality [2,14,15]. In Ethiopia, lodging occurs in teff fields every year regardless of the weather conditions and causes estimated yield losses of up to $25 \%$ [16], which can be greater than $50 \%$ in the worst cases [17]. Lodging not only lowers the yield directly but also leads to the deterioration of the quality of the crop. When rain falls during the crop's maturity growth stage, it can cause premature seed sprouting and mold growth. In addition, fear of lodging that hindered farmers in applying optimum fertilizers is a historic drawback on the efforts to maximize grain yield.

Lodging is not usually a one-time event during the growing season; rather, the crop is likely to suffer several cycles of oscillation associated with rainstorms or strong winds [18]. It is of two types: lodging caused by anchorage failure or root lodging, and lodging caused by stem mechanical failure, also known as buckling or stem lodging [19]. Stem lodging can also be defined as breaking and bending type [20]. Lodging can occur at various crop growth stages, but it occurs most often between the panicle emergence and grain filling stages. Its economic effect also varies with the time of occurrence; the earlier it occurs, the higher the economic loss [21]. The timing and severity of lodging depend on several factors, including plant population density, cultivar type, amount and timing of $\mathrm{N}$ fertilizer application, and overall crop management.

Optimization of $\mathrm{N}$ and sowing rate significantly influences the lodging of cereal crops [22-24]. A lower sowing rate has shown reduced lodging susceptibility in teff [25]. Genotypic differences in stem mechanical strength and lodging-related morphological traits have been reported in wheat [26,27], rice [28,29], and barley [30]. As these studies show, lodging is a complex phenomenon that is influenced by the environment, agronomic practices, genetic factors, and their interactions, and it is a major production constraint on cereal crops worldwide [26,30,31]. Moreover, there is no clear consensus among studies as to whether root or stem lodging predominates in cereal crops. For example, [32] investigated root lodging, whereas [33] observed stem lodging as a dominant type. A study of lodging in two cultivars of teff grown in sandy soils found root lodging to be predominant, but suggested the need for improvements in both the shoot strength and root anchorage [34].

Previous efforts to curb lodging in major cereal crops have focused on reducing the plant height by pyramiding semi-dwarfing genes into high-yielding cultivars and applying plant growth regulators. During the Green Revolution of the 1960s, the yield potential of wheat and rice was boosted significantly following the introgression of semi-dwarfing genes: reduced height-1 (Rht-B1 and Rht-D1) in wheat and semi-dwarf-1 (sd-1) in rice [35]. The mechanism was an increase in culm strength, which was associated with decreased plant height, along with a larger spike or panicle and more seeds per unit area [36]. Modern wheat and rice cultivars having these semi-dwarf genes also have a higher response 
to inputs, including fertilizers, and more efficient assimilation of photosynthates into seeds instead of vegetative growth, and therefore, a higher harvest index [37].

In recent decades, similar attempts to introduce dwarfing genes to increase lodging resistance have been carried out in teff. These efforts have centered on mutation breeding, in particular the use of physical mutagens and the TILLING (Targeting Induced Local Lesions in Genomes) technique [38,39]. This approach has been used mainly because teff is chasmogamous and completely self-pollinated with a microscopic size of the florets that makes emasculation and pollination very difficult and hinders the establishment of sufficient segregating populations. A reverse genetics approach to explore the presence and functioning of the Green Revolution genes has been also considered [40]. Through the application of these breeding techniques, a number of dwarf and semi-dwarf teff accessions have been identified and evaluated, but no lodging-resistant cultivars have been identified. A comparison of genetic improvement related to trait changes in teff and wheat [38] confirmed that the aforementioned efforts have not improved the harvest index of teff and reduced its susceptibility to lodging. This conventional approach of introducing a dwarfing gene through mutation breeding to increase lodging resistance seems unlikely to produce a semi-dwarf cultivar with sufficient lodging resistance in the near future.

Another potential strategy is to breed accessions to increase the mechanical strength of the plant stems [26]. Currently, breeding programs for various model crops are seeking to produce lodging resistance in plants with a long culm stature. In rice, for example, a recombinant inbred line with long culm stature along with high grain yield and lodging resistance has been developed [28]. Two approaches to characterize the biomechanical properties of cereals have been suggested and widely utilized. The safety factor approach where the self-weight moment of the stem could be determined using the angle of inclination from the vertical, mass of the above ground plant part, height from center of gravity, and the acceleration due to gravity [34,41,42]. This approach has not considered the main lodging factors, such as the rainfall, wind speed and the turbulence induced natural frequency of the environment. In contrast, the modeling approach developed by [43] considered both the external environmental factors and the geometry of the plant culm, particularly the section modulus. Although the former gets attention in recent studies, in reality, it is not only the self-weight moment, but also the weather conditions that are significantly important factors to lodging [44]. In addition, from practical point of view, we found the point of bending along the culm were variable in the teff accessions included in this study, which makes measurement of the angle of inclination at a similar position difficult.

The objectives of this study were therefore to examine the variability of stem mechanical properties and agro-morphological traits, together with trait associations with lodging, in landrace accessions of teff, and then to infer possible selection criteria for developing lodging-resistant cultivars. We expect the findings of this study to be a useful resource for related biomechanical studies and for developing future strategies for improving lodging resistance in teff.

\section{Materials and Methods}

\subsection{Description of the Study Sites}

This study was carried out during the main cropping seasons in 2018 and 2019 at Adet $\left(11^{\circ} 28^{\prime} \mathrm{N}\right.$, $37^{\circ} 48^{\prime} \mathrm{E} ; 2216 \mathrm{~m}$ a.s.l) and Bichena $\left(10^{\circ} 46^{\prime} \mathrm{N}, 38^{\circ} 19^{\prime} \mathrm{E} ; 2541 \mathrm{~m}\right.$ a.s.l) experimental stations, operated by the Adet Agricultural Research Center, northwestern Ethiopia. Adet and Bichena are located 42 and $222 \mathrm{~km}$, respectively, southwest of Bahir Dar city. Average maximum daily temperatures during the growing period (July to December) of the study years were similar at the two stations, but average minimum daily temperatures differed between the stations, particularly during the early crop growth stages (July to September) (Figure 1). The rainfall distribution pattern which is a unimodal mostly occur from June to September varied considerably between them. The sites also differed in soil type and soil physicochemical properties (Table 1). At Adet, the soil is a well-drained brown Nitosol, whereas at Bichena, the soil is a black Vertisol with a high water-holding capacity and poor drainage. 
The study locations are therefore distinct and represent the two mega-teff growing environments of the northwestern part of the country.

Table 1. Soil chemical properties of the test sites in the top $0-15 \mathrm{~cm}$ depth.

\begin{tabular}{cccccccc}
\hline Study Site & $\mathbf{p H}$ & $\begin{array}{c}\mathrm{EC}^{*} \\
(\mathbf{d S} / \mathbf{m})\end{array}$ & $\begin{array}{c}\text { Total N } \\
(\mathbf{g} / \mathbf{k g})\end{array}$ & $\begin{array}{c}\text { Available } \\
\mathbf{P}(\mathbf{m g} / \mathbf{k g})\end{array}$ & $\begin{array}{c}\text { Exchangeable K } \\
(\mathbf{c m o l}(+) / \mathbf{k g})\end{array}$ & $\begin{array}{c}\text { Available Mn } \\
(\mathbf{m g} / \mathbf{k g})\end{array}$ & $\begin{array}{c}\text { Available } \\
\mathbf{S}(\mathbf{m g} / \mathbf{k g})\end{array}$ \\
\hline Adet & 5.17 & 0.07 & 1.57 & 27.69 & 0.88 & 78.12 & 48.09 \\
Bichena & 5.85 & 0.08 & 1.04 & 35.23 & 1.34 & 31.52 & 31.88 \\
\hline
\end{tabular}

* Electrical conductivity of the soils.

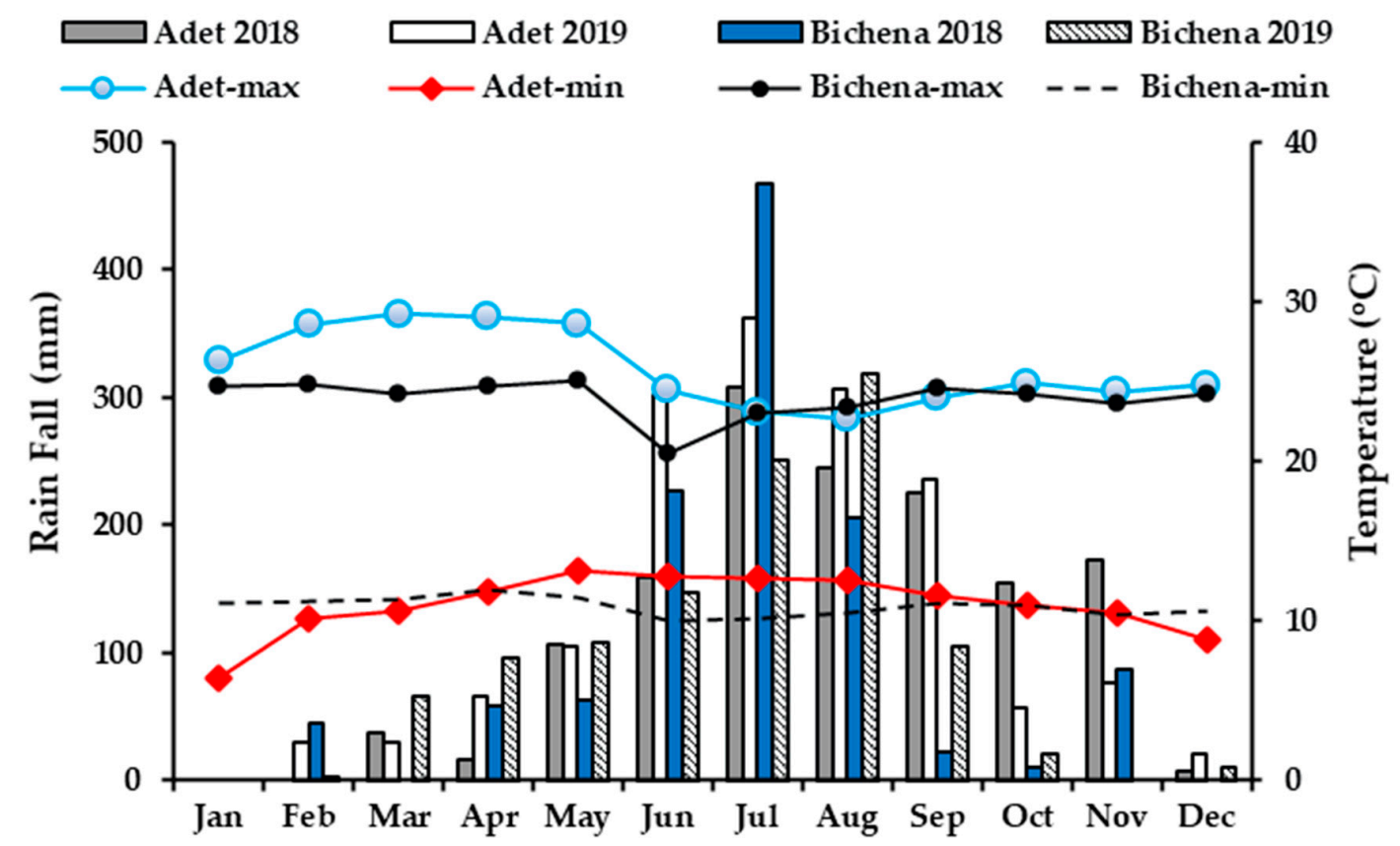

Figure 1. Monthly rainfall distribution (bars), maximum daily average temperature (max), and minimum daily average temperature ( $\mathrm{min}$ ) at the Adet and Bichena experimental stations during 2018 and 2019. The temperature data shown for each station are the averaged values of the two years. These data were provided by the Ethiopian Meteorology Agency, Bahir Dar region.

\subsection{Population Panels and Design}

The population panels included in this study were accessed from Adet and Debre-Zeit Agricultural Research Center teff breeding programs and from the Ethiopian Biodiversity Institute. Prior to the establishment of the field experiment, the true to types of each genotype were maintained in two consecutive cycles of head to row selection. A total of 320 teff genotypes (mostly landrace accessions, except for six improved cultivars: Tsedey, Dega-teff, Etsub, Quncho, Abola, and Cora) were planted in an $8 \times 40$ alpha lattice design with two replications. Each plot was $2 \mathrm{~m}$ long and $0.6 \mathrm{~m}$ wide and composed of three rows with $0.2 \mathrm{~m}$ between rows. Seeds were sown in each row by hand drilling and were not covered over with soil. Three weeks after seedling emergence, thinning and transplanting were carried out to maintain an 8-cm spacing between plants, with two seedlings in each hill. Then, the rows were covered with soil. Teff was planted in mid-July at Adet station and in the first week of August at Bichena station in both years, following the local farming practice. N, P, and S fertilizers were applied in the form of urea $(46 \% \mathrm{~N})$ and NPS $(19 \% \mathrm{~N}, 38 \% \mathrm{P}, 7 \% \mathrm{~S})$. N was applied at $64.5 \mathrm{~kg} / \mathrm{ha}$ at Adet and $87.5 \mathrm{~kg} / \mathrm{ha}$ at Bichena. Equal rates of $\mathrm{P}(60 \mathrm{~kg} / \mathrm{ha})$ and $\mathrm{S}(11 \mathrm{~kg} / \mathrm{ha})$ were applied at the two stations. All of the P and S and half of the $\mathrm{N}$ were applied at planting, and the remaining half of the $\mathrm{N}$ was applied at the tillering stage. Harvesting was done in the third week of November and December for Adet and Bichena stations, respectively. 


\subsection{Measurements and Data Collection}

Data regarding agro-morphological traits and biomechanical properties were collected timely during the growing seasons following standard methods and procedures. Data were collected on either a plot or a plant basis. Plant height, panicle length, peduncle length, tiller number per plant, and panicle weight were determined on a plant basis from five representative plant samples collected from each plot. Internode diameter, wall thickness and the biomechanical properties (the internode breaking strength - the maximum force that the internode withstands before it failed) were measured using the same five samples. Pushing resistance, another biomechanical property, were measured at the heading stage of the crop. Grain yield was determined on a plot basis: each plot was harvested at physiological maturity, and then the crop was allowed to dry for a week in the sun before being threshed.

\subsubsection{Visual Lodging Score and Lodging Index}

The visual lodging score (LIV) was determined on a plot basis by the method outlined by [45]. In this method, a score from 0 to 5 is assigned on the basis of the angle of lodging (leaning) from the vertical $(0=$ no lodging, with all plants upright; $5=$ completely lodged, with all plants prostrate) and the percentage of plants in the plot exhibiting each degree of leaning. The score was then calculated as the $\sum$ (lodging score $\times \%$ severity) $/ 5$. Lodging index (LI) of the second basal internode was determined following the formula: $L I=($ Bending moment/Breaking resistance $) \times 100$ as described elsewhere [46].

\subsubsection{Pushing Resistance}

Five hills were selected randomly from each plot when the crop was at the heading stage, and the pushing resistance of the whole plant, including tillers, was measured at a height of $20 \mathrm{~cm}$ above the ground with a prostrate tester (Daiki Rika Kogyo Co. Tokyo, Japan-model: DIK-7401). The device was positioned perpendicular to the plant stem at the height described above and pushed until the stem was bent $45^{\circ}$ from the vertical position while maintaining the perpendicularity of the device throughout. The detailed procedures followed are outlined elsewhere [47-49]. The measurement was recorded in millimeters using the white spring $(9.8 \mathrm{~N} / 40 \mathrm{~mm})$ and then converted to units of force by referring to the conversion chart provided by the company.

\subsubsection{Culm Breaking Strength and Bending Moment}

Samples of healthy culms were collected from each plot when the crop was near to physiological maturity. Each accession was sampled as it approached its maturity stage. Leaves and leaf sheaths were trimmed, and each internode was separated carefully. A flat smooth wooden table with two nails was used for a three-point bending test. The two nails were hammered a short way into the table top, $8 \mathrm{~cm}$ apart to test internodes that were $\geq 10 \mathrm{~cm}$ long and $6 \mathrm{~cm}$ apart for internodes that were $<10 \mathrm{~cm}$ long. The internode was laid across the nail heads and then a digital force gauge was used to apply a downward force at its center. The maximum force $\left(\mathrm{F}_{\max }\right)$ that the internode can withstand before it failed was recorded. Based on this value, the second basal internode breaking strength was calculated as $S_{S}=F_{\max } \times L / 4$, where $L$ is the distance between the supporting points as described in $[47,50]$. The outer diameter and wall thickness of each internode were measured with a digital caliper of $0.01 \mathrm{~mm}$ accuracy. It is obvious that the plant culm deviates from a perfect hollow circular cross section, which is usually oval. The outer diameter was then measured both in the major and minor radius at the mid-point of the internode and the average was used for the downstream calculation. Since accessions with thin culm were included in the study, direct measurement of the inner diameter was not appropriate. Instead, the internodes were dissected vertically with razor blade and the wall thickness was measured along the groove. The difference between the average outer diameter and the wall thickness was considered as the inner diameter. The maximum second basal internode bending stress $(\sigma)$ usually used to define the material strength was determined following Equation (1) by simplifying the ratio of breaking strength to section modulus as describe elsewhere [19,47]. 
The geometry of the internode, i.e., second moment of area (I) and section modulus (SM), was computed using the standard mechanical Equations (1) and (2) respectively. Failure moment (BS) of the second basal internode were calculated as described by [43] and later used by [19,26] using Equation (4) under the assumption that the teff stem had a hollow circular cross section:

$$
\begin{gathered}
\sigma=\frac{L \times R \times F_{\max }}{\left(R^{4}-r^{4}\right)} \\
I=\frac{\pi\left(R^{4}-r^{4}\right)}{4} \\
S M=\frac{\pi\left(R^{4}-r^{4}\right)}{4 R} \\
B S=\frac{\sigma \pi R^{3}}{4}\left(1-\left(\frac{R-t}{R}\right)^{4}\right)
\end{gathered}
$$

where $\boldsymbol{F}_{\max }$ is the maximum force that the internode could withstand before it broke or failed, $\boldsymbol{L}$ is the distance between the supports (nails), $I$ is the second moment of area, $t$ is the internode wall thickness, and $\boldsymbol{R}$ and $\boldsymbol{r}$ are the outer and inner radius, respectively, of the internode.

\subsection{Root Characterization}

To characterize the roots, fifteen selected accessions were planted based on the first-year field phenotyping results. Plant height, panicle weight, and lodging response were the main selection criterion and contrasting accessions were included in the study. A 1-m long and 20-cm in diameter PVC tubes were prepared by dissecting vertically and fastened tightly with a wire rod at two positions. The tubes were then buried vertically in a $90 \mathrm{~cm}$ depth pit prepared under a screen house. Uniformly mixed soils of Nitosol and sand in a 3:1 Ratio were filled into each PVC and slight compaction with sticks was made. Seedlings were grown in small pots separately and two three-week old seedlings were then transplanted into each PVC tube. N, P, and S fertilizers were applied using the optimum recommendation rates of Adet experimental stations as described above. Irrigation was done every day early in the morning. During the maturity stage of the crop, the above ground biomass was harvested and roots was carefully washed with water using "GARDENA" Comfort Multi Sprayer.

\subsection{Data Analysis}

Analysis of variance and mean comparisons were performed using the Proc ANOVA model of the alpha lattice design in the Statistical Analysis System software program [51]. The statistical significance of mean differences was computed by using the Tukey test; $p<0.05$ was considered significant. To identify traits that the future breeding program has to focus, multiple linear regression and principal component analysis (PCA) were performed. The PCA was computed in RStudio using autoplot function of ggplot2. Statistical Package for Social Sciences (SPSS v.16) was also used for multicollinearity test and multiple linear regression analysis. The Pearson correlation coefficients and its significant test between all the possible pair of the biomechanical properties and agro-morphological traits was determined following the Proc CORR procedure of SAS. All charts were computed using the excel spreadsheet of Microsoft Office v.16. It is worthy to mention that the crop performance during the 2019 season at Bichena station was generally stunted and measurements on the biomechanical properties was not done intending this might mislead the analysis and inference of the results. Data collected over 2 years at Adet and 1 year at Bichena stations were therefore used for the analyses. 


\section{Results}

\subsection{Agro-Morphological Trait Variability}

All traits showed significant differences among the tested genotypes (Table 2). Panicle + peduncle length accounted for $50-67 \%$ of the total plant height with a mean of $59 \%$. The panicle length to culm ratio ranged from 0.31 to 0.70 , with an average of 0.51 . Thus, panicle length accounted for $51 \%$ of the culm length and $34 \%$ of the total plant height. Peduncle length accounted for nearly $38 \%$ of the culm length (range, $21-54 \%$ ) and for about $26 \%$ of the total plant height (Table 3). The internode diameter, which was largest at the base of the plant and decreased upward, was significantly different within and between environments. It was generally larger at Adet than at Bichena, and also found to be higher in 2018 than in 2019 (Figure 2). Plant height and grain yield were greater at Adet than at Bichena. The lodging index based on visual score was generally lower at Bichena than at Adet during both years.

Table 2. Mean squares and statistical significance test of the traits based on combined analysis of variance.

\begin{tabular}{|c|c|c|c|c|c|c|c|}
\hline \multirow{2}{*}{ Trait } & \multicolumn{5}{|c|}{ Sources of Variation ${ }^{1}$} & \multirow{2}{*}{$\%$ Explained $^{2}$} & \multirow{2}{*}{ CV $(\%)$} \\
\hline & G & $\mathbf{E}$ & $\mathbf{G} \times \mathbf{E}$ & $\mathbf{R}$ & $\mathbf{B}(\mathbf{R})$ & & \\
\hline Plant height & $759.4^{* *}$ & $85,122.3^{* *}$ & $13.3^{\mathrm{ns}}$ & $3731.9 * *$ & $1512.9^{* *}$ & $1.7(49.4)$ & 6.8 \\
\hline Panicle length & $194.5^{* *}$ & $24,600.8^{* *}$ & $15.1 * *$ & $406.2 * *$ & $236.3^{* *}$ & $7.6(49.2)$ & 3.7 \\
\hline Culm length & $304.0 * *$ & $18,103.6^{* *}$ & $22.6^{* *}$ & $6263.6^{* *}$ & $654.7^{* *}$ & $8.1(54.4)$ & 6.1 \\
\hline Peduncle length & $78.7 * *$ & $2421.1 * *$ & $0.237^{\mathrm{ns}}$ & $587.5^{* *}$ & $102.3^{* *}$ & $0.43(70.8)$ & 7.4 \\
\hline Tiller number & $42.8^{* *}$ & $1390.2^{* *}$ & $11.2^{* *}$ & $122.7^{* *}$ & $25.2 * *$ & $23.4(44.9)$ & 18.1 \\
\hline Panicle weight & $0.404^{* *}$ & $47.8^{* *}$ & $0.099 * *$ & $0.139^{\mathrm{ns}}$ & $0.346^{* *}$ & $18.5(37.7)$ & 20.8 \\
\hline Grain yield & $1.99 * *$ & $144.3^{* *}$ & $0.026^{\mathrm{ns}}$ & $1.29 * *$ & $2.64 * *$ & $1.6(62.3)$ & 9.6 \\
\hline Lodging score visual & $1352.5^{* *}$ & $18,091.2^{* *}$ & $519.7 * *$ & $4.31^{\mathrm{ns}}$ & $885.0^{* *}$ & $34.4(44.8)$ & 18.4 \\
\hline Lodging index & $22,493.2^{* *}$ & $60,424.7^{* *}$ & $10,925.7^{* *}$ & $5.29 \mathrm{~ns}$ & $171.8^{\mathrm{ns}}$ & $10.2(21.1)$ & 2.58 \\
\hline Diameter & $0.819^{* *}$ & $29.7^{* *}$ & $0.043^{\mathrm{ns}}$ & $17.2^{* *}$ & $1.39 * *$ & $6.5(61.4)$ & 8.4 \\
\hline Pushing resistance & $92.25 * *$ & $16,066.3^{* *}$ & $9.26^{\mathrm{ns}}$ & $1838.5^{* *}$ & $251.5^{* *}$ & $5.0(49.7)$ & 18.7 \\
\hline 2nd moment of area & $4.5^{* *}$ & $146.4^{* *}$ & $0.27^{* *}$ & $89.0 * *$ & $9.8^{* *}$ & $7.6(63.7)$ & 25.7 \\
\hline Section modulus & $1.35^{* *}$ & $50.5^{* *}$ & $0.061^{* *}$ & $27.8^{* *}$ & $2.82 * *$ & $5.6(63.4)$ & 19.9 \\
\hline Base failure moment & $0.027 * *$ & $1.94^{* *}$ & $0.0006^{\mathrm{ns}}$ & $0.51^{* *}$ & $0.055^{* *}$ & $2.57(58.4)$ & 11.8 \\
\hline
\end{tabular}

${ }^{1} \mathrm{G}=$ genotype, $\mathrm{E}=$ environment, $\mathrm{G} \times \mathrm{E}=$ genotype by environment interaction, $\mathrm{R}=$ replication, $\mathrm{B}(\mathrm{R})=\mathrm{block}$ within replications, $\mathrm{CV}=$ coefficient of variation, $\mathrm{ns}=$ non-significant, ${ }^{* *} p<0.01 .{ }^{2}$ Percent explained by genotype by environment interaction (values outside the parenthesis) and genotype (values in parenthesis) from the total sum of squares. 


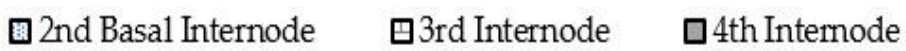

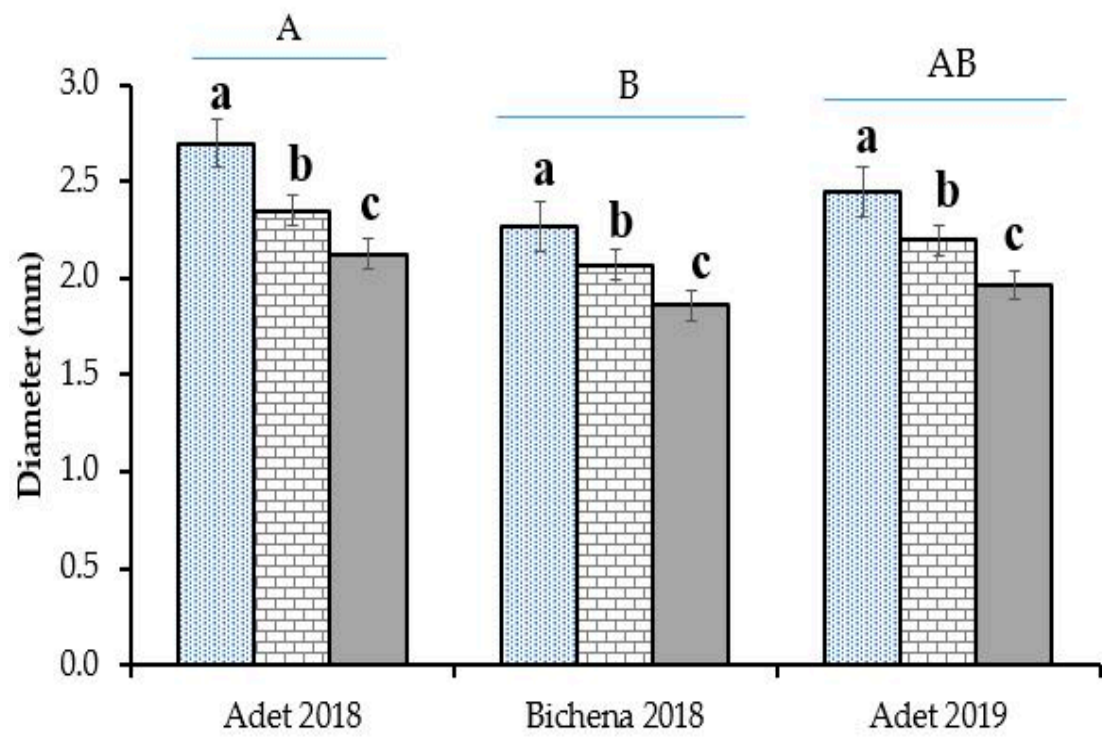

Figure 2. Internode and culm diameter trends across locations and years and along plants (internodes were counted from the ground upward). The same uppercase letters above bars indicates no significant differences $(p<0.05)$ among environments for the average culm outer diameter, and the lowercase letters indicates the significant difference between internode outer diameter within a culm.

Table 3. Descriptive statistics of agro-morphological traits and biomechanical properties of tested teff accessions based on mean values of data from the three environments (location $\times$ year combination).

\begin{tabular}{|c|c|c|c|c|}
\hline Variable & Minimum & Maximum & Mean & SD * \\
\hline Plant height $(\mathrm{cm})$ & 74.00 & 135.00 & 100.17 & 11.22 \\
\hline Panicle length $(\mathrm{cm})$ & 19.40 & 51.57 & 33.87 & 5.69 \\
\hline Culm length $(\mathrm{cm})$ & 49.10 & 87.17 & 66.30 & 7.12 \\
\hline Peduncle length $(\mathrm{cm})$ & 14.10 & 35.23 & 25.26 & 3.62 \\
\hline Tiller number per plant & 8.57 & 28.30 & 14.35 & 2.67 \\
\hline Panicle weight $(\mathrm{g})$ & 0.46 & 2.20 & 1.09 & 0.26 \\
\hline Grain yield (t/ha) & 0.89 & 3.52 & 2.18 & 0.58 \\
\hline Lodging score visual (\%) & 22.00 & 100.00 & 65.54 & 16.09 \\
\hline Lodging index $(\%)$ & 132.0 & 155.0 & 140.5 & 2.39 \\
\hline 2nd basal internode diameter ( $\mathrm{mm})$ & 1.51 & 3.89 & 2.47 & 0.37 \\
\hline Pushing resistance at heading $(\mathrm{N})$ & 1.59 & 7.47 & 3.85 & 1.18 \\
\hline 2nd moment of area $\left(10^{-12} \mathrm{~m}^{4}\right)$ & 0.15 & 6.31 & 1.44 & 0.87 \\
\hline Section modulus $\left(10^{-9} \mathrm{~m}^{3}\right)$ & 0.19 & 3.27 & 1.06 & 0.47 \\
\hline Base failure moment $(\mathrm{Nm})$ & 0.03 & 0.25 & 0.11 & 0.03 \\
\hline Culm length to plant height ratio & 0.59 & 0.76 & 0.66 & 0.03 \\
\hline Panicle + peduncle length to height ratio & 0.50 & 0.67 & 0.59 & 0.03 \\
\hline Peduncle length to plant height ratio & 0.13 & 0.41 & 0.26 & 0.05 \\
\hline Panicle length to plant height ratio & 0.24 & 0.41 & 0.34 & 0.03 \\
\hline Panicle length to culm length ratio & 0.31 & 0.70 & 0.51 & 0.07 \\
\hline Peduncle length to culm length ratio & 0.21 & 0.54 & 0.38 & 0.06 \\
\hline
\end{tabular}

* SD: standard deviation.

Tiller number, one of the most important traits that influence both grain yield and lodging resistance, exhibited a wider range among the accessions. It ranged from 9 to 28 with the highest values observed on dwarf cultivars. Peduncle length exhibited the highest genotypic variability among the traits. In most of the cases, the longer the peduncle, the shorter the panicle length observed. 
Panicle weight and panicle length also varied significantly among the accession in all the environments (Supplementary Table S1). Although for some traits the interaction of genotype by environment was significant, its contribution to the total sum of squares was minimal (Table 2). However, genotypic ranks for plant height, panicle length, internode diameter, panicle weight, pushing resistance, and base failure moment were consistent across the environments as a non-significant genotype by environment interaction was revealed (Table 2).

\subsection{Comparison of Genotypes}

We classified the population panels into four groups (dwarf, semi-dwarf, tall, and very tall) according to plant height, with the improved cultivars included as a fifth group (control), and then compared for important traits among these groups (Figure 3). The mean values of the biomechanical properties and agro-morphological traits of the improved cultivars were generally equivalent to those of the tall group, except that the grain yield of the control group was similar to that of the very tall group. In most traits, the mean values of the dwarf and semi-dwarf accession groups were lowest, except for tiller number. Mean values of base failure moment, section modulus, and pushing resistance were highest in the very tall group. In general, tall genotypes were characterized by a larger internode diameter, longer panicle, heavier panicle weight, and higher grain yield than the dwarf genotypes. Even though some accessions in the very tall group were highly susceptible to lodging, this group also included accessions identified as having both relatively high lodging resistance and good yield potential. In particular, accessions 123 (203010-4) and 149 (55114-4) in the very tall group and accession 7 (234430-1) in the tall group were characterized by high internode diameter and base failure moment values, a low tiller number, a smaller lodging score, and a good yield potential.

\subsection{Mechanical Properties and Lodging Index}

We evaluated the plant base failure moment, section modulus, and pushing resistance of the stem (see Section 2.3). The ANOVA results showed a significant difference among the genotypes in plant base failure moment, second moment of area, and the section modulus (Table 2). Plant base failure moment ranged from 0.06 to $0.50 \mathrm{Nm}$ with a mean value of $0.22 \mathrm{Nm}$. Pushing resistance ranged from 1.59 to $7.47 \mathrm{~N}$ (mean, $3.85 \mathrm{~N}$ ), second moment of area from 0.15 to $6.3 \times 10^{-12} \mathrm{~m}^{4}$ (mean, $1.4 \times 10^{-12} \mathrm{~m}^{4}$ ), and section modulus values from 0.19 to $3.27 \times 10^{-9} \mathrm{~m}^{3}$ (mean, $1.06 \times 10^{-9} \mathrm{~m}^{3}$ ).

The lodging index based on visual score was generally smaller at Bichena than at Adet during both years. It ranged from $22 \%$ to $100 \%$ at Adet and from $12.5 \%$ to $100 \%$ at Bichena. Accessions 123 and 149 had the lowest values. Similarly, the lodging index based on the mechanical properties was higher at Adet than Bichena. The higher lodging index was observed on accessions in the very tall group whereas the dwarf group showed the lowest. Accession 123 had a loose panicle form and a relatively high standing ability, but the lateral growth pattern of the tillers led to some bending (Figure 4B). In contrast, accession 149 had a compact panicle form and the lower stem had good standing ability, but bending and some breaking occurred at the neck or peduncle (Figure 4A). Both accessions had deep roots and a high root length density (data not shown). Generally, most accessions showed bending-type stem lodging, although some exhibited breaking-type stem lodging (Figure 4C,D). 

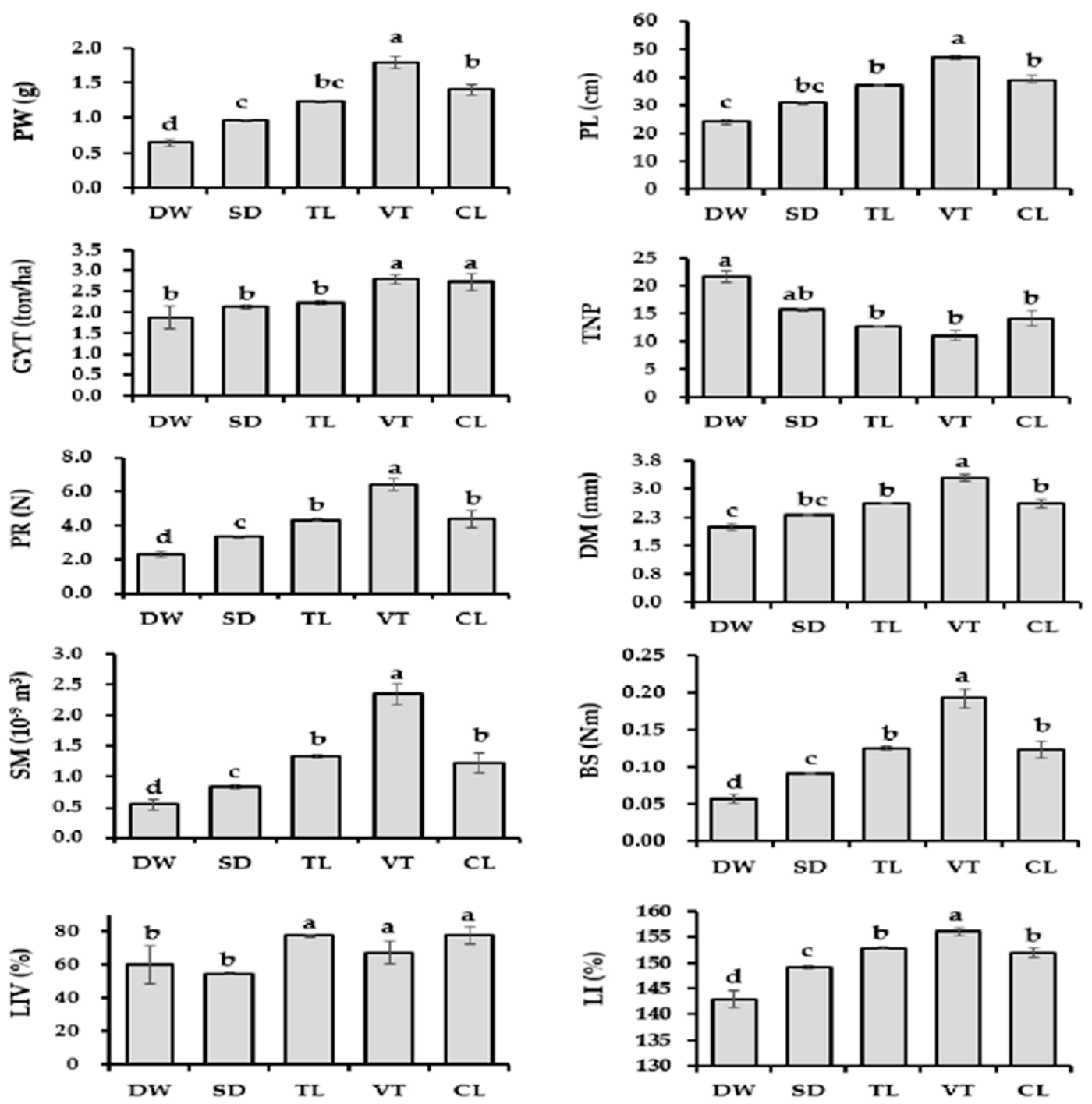

Figure 3. Comparison of genotypes by height group: Dwarf (DW), $\leq 80 \mathrm{~cm}$; Semi-dwarf (SD), $81-100 \mathrm{~cm}$; Tall (TL), 101-120 cm; Very Tall (VT)), $\geq 121 \mathrm{~cm}$ and improved cultivars (CL). The CL group comprises the averaged values of the six improved cultivars. Error bars indicate standard error. The same letter above bars indicates no significant differences between the groups $(p<0.05)$. The measured or calculated traits are panicle weight (PW), panicle length (PL), grain yield (GY), tiller number per plant (NTP), pushing resistance (PR), second basal internode diameter (DM), section modulus (SM), base failure moment (BS), Lodging index (LI), and Peduncle length (PDL). 


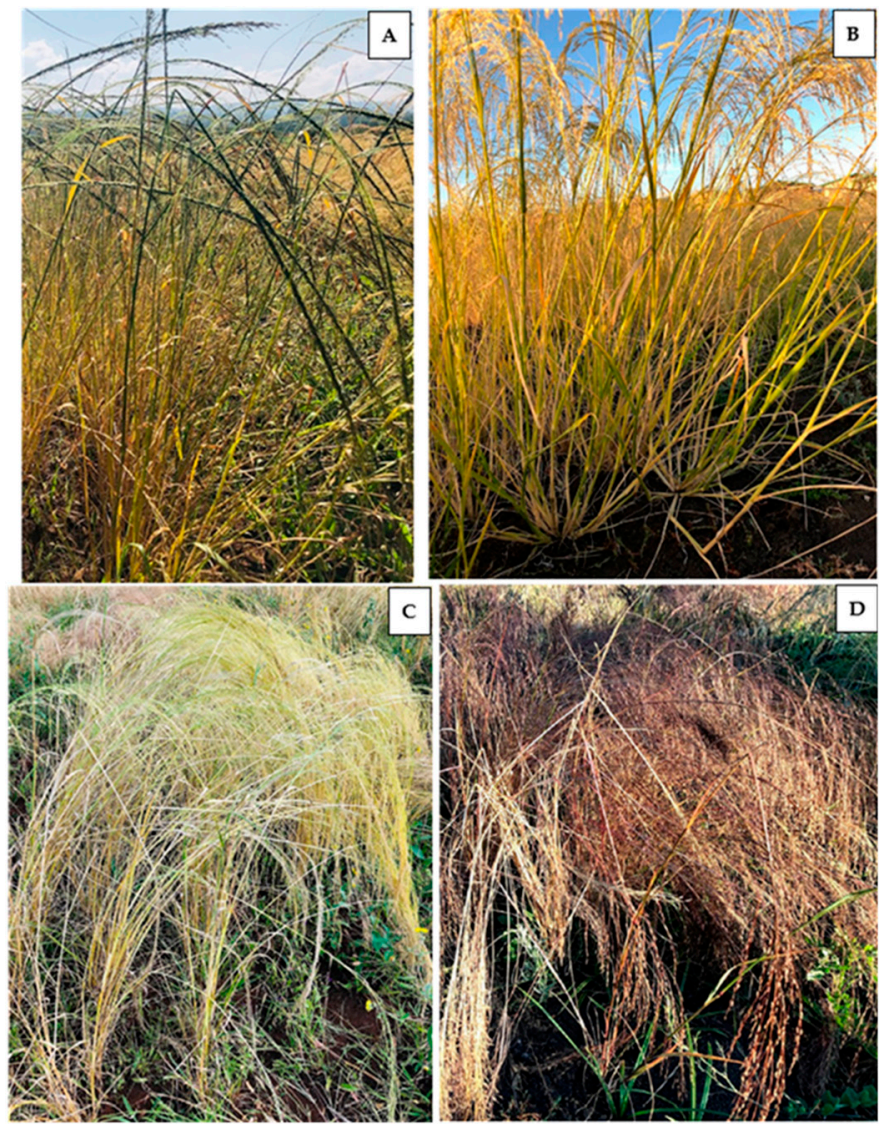

Figure 4. Lodging in selected teff accessions. (A) Accession 149 (55114-4). Although this accession has good standing ability at the plant base, it failed at the panicle neck. (B) Accession 123 (203010-4), this accession has relatively good lodging resistance but lateral tiller growth. (C) accession 201 (RIL-2) were susceptible to bending-type lodging. (D) Accession 63 (235368-1), with typical breaking-type stem lodging.

\subsection{Trait Associations}

The relationships of plant height with pushing resistance during heading, plant base failure moment, the section modulus and Lodging index were linear and positive, with $R^{2}$ values of $0.39,0.55$, 0.44 , and 0.35 respectively (Figure 5a). Similarly, the relationships of the section modulus with plant base failure moment, and pushing resistance were positive and significant (Figure 5b). The association of plant height and section modulus with lodging index is generally significantly positive. However, the association between section modulus and lodging index also shows a negative relationship for some sub-populations. The slope of the relationship between base failure moment and the section modulus (the maximum bending stress, an indication of the of material strength) differed significantly among the genotypes tested. Stem diameter, one of the traits used to characterize lodging, was positively related to plant height $(\mathrm{r}=0.66, p<0.01)$. Plant height, internode diameter, panicle weight, and panicle length correlated positively with each other and with the internode mechanical properties (Supplementary Table S2). The tiller number per plant, however, was negatively correlated with most traits, including the internode mechanical properties and lodging index (Figure 5c,d and Supplementary Table S2). 

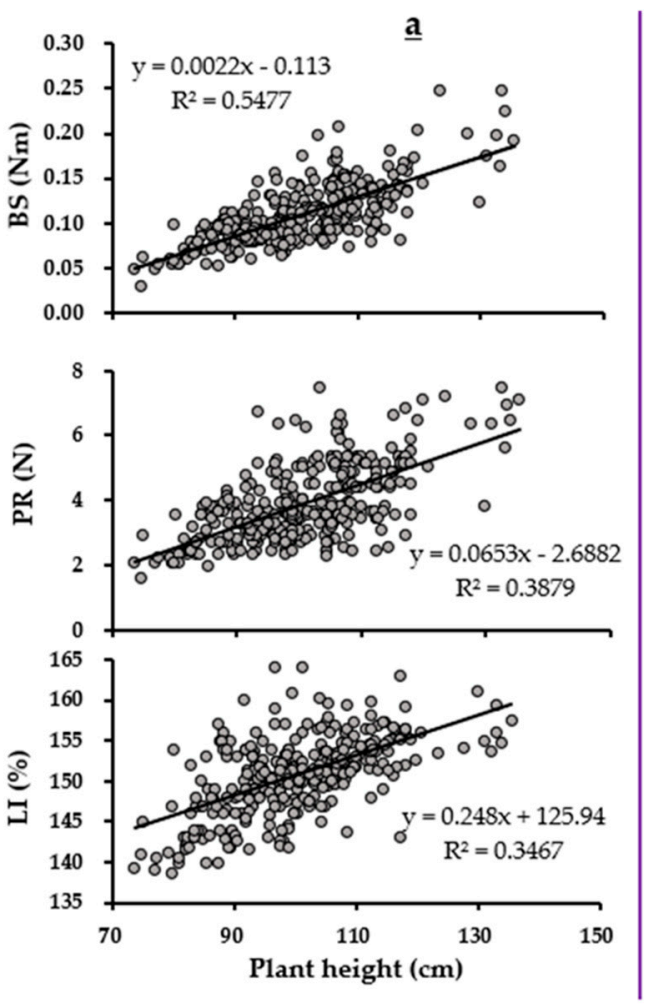

$\underline{\mathbf{c}}$

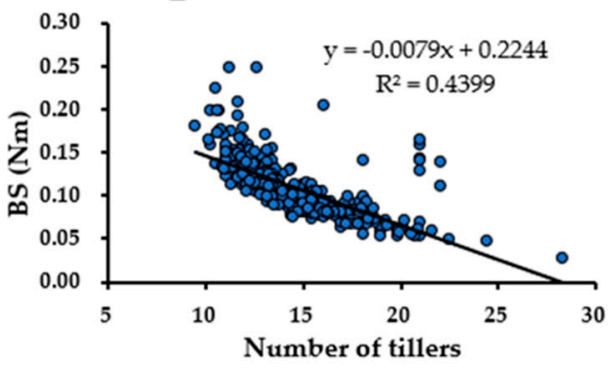

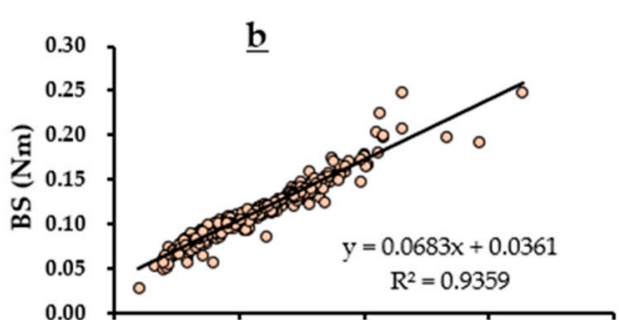
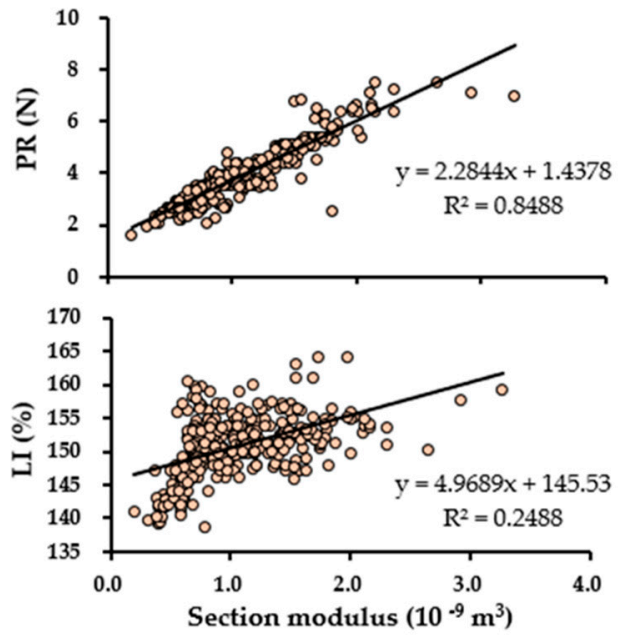

$\underline{\mathbf{d}}$

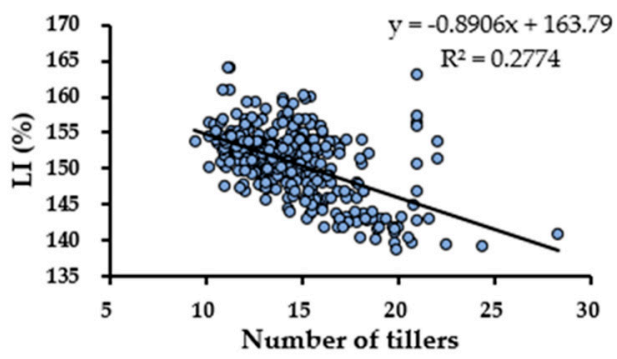

Figure 5. Bivariate analysis showing the relationship of the traits (320 genotypes): (a), the relationship of plant height with lodging index (LI), pushing resistance (PR) and base failure moment (BS); (b), the relationship of section modulus with lodging index (LI), pushing resistance and base failure moment; (c), relationship between number of tillers and base failure moment; and (d), number of tillers versus lodging index.

\subsection{Root Characteristics}

The root characterization results showed significant differences in root system depth, root depth density, and the root to shoot ratio among the selected accessions. Despite the general consensus that teff has a shallow root system, root system depth and the root to shoot ratio were high in these accessions. Root system depth ranged from 56.7 to $105.3 \mathrm{~cm}$, with a mean of $92.5 \mathrm{~cm}$. The vertical root growth was proportional to the aboveground growth. Plant height ranged from 68 to $130 \mathrm{~cm}$, with a mean of $106 \mathrm{~cm}$ which was comparable with the field observations. The root system depth and root depth density of the dwarf accessions were lower (Figure 6(b2,b3)) than those of the tall accessions and the improved cultivar Quncho (Figure 6(b1,b4,b5)). The thickness of individual roots was not measured, but they were very thin and abundant and distributed throughout the volume of the PVC tubes (Figure 6a). 


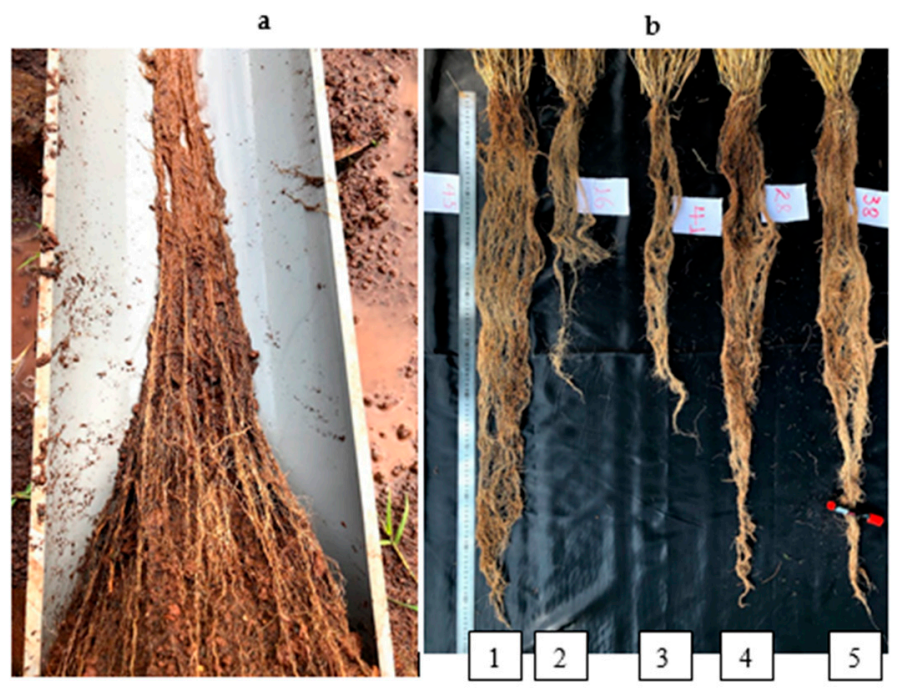

Figure 6. Root systems of selected teff accessions after the PVC experiment. (a) Accession 149 during washing. (b) Roots of the selected accessions after drying: $1=149$ (55114-4), $2=30$ (234431-1), $3=116$ (204596-2), 4 = 202 ('Quncho), 5 = 123 (203010-4).

\subsection{Trait Contributions to Lodging}

Plant base failure moment was among the parameters used to assess the mechanical properties of the plant stem. We carried out a multiple linear regression analysis with that as the dependent variable. Because of multicollinearity, most traits were excluded from the model. The results showed that pushing resistance at the heading stage, plant height, tiller number, and panicle weight were significantly contributed to the observed variation in base failure moment and together explained about $92 \%$ of the variance. Pushing resistance at the heading stage and plant height had the largest positive effect, and tiller number had a significant negative effect, on plant base failure moment (Table 4).

Table 4. Multiple linear regression results with base failure moment as the dependent variable.

\begin{tabular}{ccccc}
\hline Variables & Coefficient & Std. Error & $\boldsymbol{t}$-Statistic & $\boldsymbol{P}$ \\
\hline Constant & 0.052 & 0.147 & 0.354 & 0.724 \\
Plant height & 0.143 & 0.001 & 4.592 & 0.000 \\
Tiller number & -0.141 & 0.004 & -4.615 & 0.000 \\
Panicle weight & 0.057 & 0.039 & 2.161 & 0.031 \\
Pushing resistance & 0.709 & 0.008 & 29.96 & 0.000 \\
\hline $\boldsymbol{R}^{\mathbf{2}}$ & 0.922 & Residual mean square & 0.012 \\
Adjusted $R^{2}$ & 0.921 & F-statistic & 930.1 \\
Std. error of & 0.108 & Probability (F-statistic) & 0.000 \\
regression & & &
\end{tabular}

Similarly, the principal component analysis (PCA) (Figure 7) found pushing resistance, diameter, section modulus, base failure moment, panicle weight and plant height having the highest positive loading on the first component (PC1). The mechanical properties, namely pushing resistance, section modulus, and base failure moment, clustered with the second basal internode diameter which is indicated by the circle in the PCA plot. Accessions 201 (RIL-2), 123 (203010-4), 232 (237703-4), 20 (237707-1), and 149 (55114-4) and Cora, were among the improved cultivars as indicated by the arrow in the PCA had high positive loadings on PC1. In contrast, tiller number (TNP) was the only trait with a strong negative loading on PC1. Dwarf accessions in general and accession 30 (234431-1) in particular showed the highest negative loading on PC1 due to the highest in tiller number per plant and the lowest in biomechanical properties. 


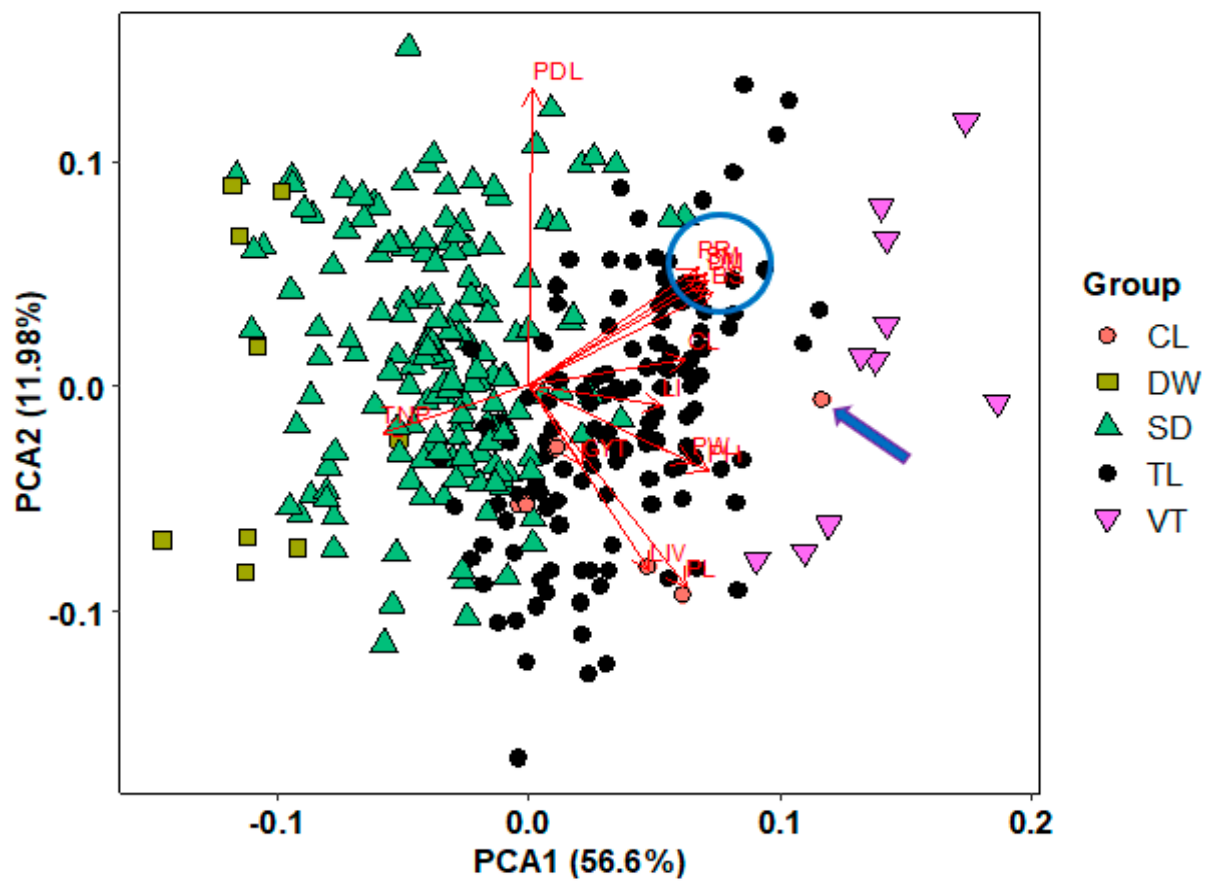

Figure 7. Principal component analysis results for the 13 agro-morphological and biomechanical traits of the 320 teff genotypes. The length of vectors indicates the loading of each trait and the angle between vectors indicates the relationship among the traits: number of tillers per plant (TNP), peduncle length (PDL), panicle length (PL), lodging score (LIV), plant height (PH), panicle weight $(\mathrm{PW})$, culm length (CL), second basal internode diameter (DM), grain yield (GYT), pushing resistance (PR), section modulus (SM), second moment of area (MI), base failure moment (BS), and lodging index (LI). The Group refers to the plant height-based classification of the genotypes as described in Figure 3.

\section{Discussion}

This study has investigated the variability and interrelationships of the culm biomechanical properties and agro-morphological traits of teff for lodging resistance. The grain yield performance of the improved cultivar group (Control) were comparable with the very tall accessions group. However, the improved cultivars were significantly lower in terms of internode diameter, pushing resistance, base failure moment, and lodging index. This clearly indicates the presence of untapped variations for important lodging related traits in teff accessions that can be exploited in the breeding program. Although not significant, the very tall group showed a relatively lower visual lodging score and significantly higher lodging index which further indicated the presence of a few accessions relatively better in terms of lodging resistance. It is important to note that the higher performance of the very tall group in terms of panicle weight and length, which seems not to hold for grain yield, likely diminishes the visibility of lodging resistance in the group. The lower lodging score at Bichena was due to the low $\mathrm{N}$ content of the soil there. In addition, at Bichena, the midterm drought persisted throughout September during 2018 and affected the growth and tillering capacity of the crop. Rainfall, particularly from the grain filling stage to maturity (October to December), was higher at Adet than at Bichena, indicating that rainfall might account for the greater lodging observed at Adet station. Except a significant negative correlation with panicle length and positive relation with plant height, peduncle length showed no significant relationship with most of the traits. This implies the higher probability to reduce the plant height by reducing the peduncle length of teff through continues breeding. The significant negative relationship of tiller number per plant with lodging index and all of the biomechanical properties considered in this study suggested that suppressing the tillering capacity of the future cultivars might contribute towards enhanced lodging resistance in teff. It will be worthy to note that the observed relatively higher genotype by environment interaction on lodging index and tiller number may signify the quantitative inheritance pattern of the traits which could slow the genetic gain under selection. 
The observed root system depths, root to shoot ratios, and pushing resistance of the stubble are consistent with our observation that root lodging was minimal in the accessions tested. We carefully checked whether displacement of the root cone or uprooting was more likely in lodged plants but we did not observe any differences between lodged and unlodged plants at field condition. In addition, the stubble remaining after the crop was harvested tended to turn back to its upright position, whereas the stubble of root-lodged plants would be expected to remain bent even after the removal of most of the aboveground biomass. The observations indicate that stem failure might account more than root failure for lodging in teff. However, our observations that the tillers initially grew mainly laterally and start to hold upright later in the growth stage further implies space competition at the crown, and teff has a relatively narrow root-shoot jointing point (crown) (Figure 6) compared with other cereal crops, which is in agreement with previous findings [34]. These suggests root failure could not be ruled out and needs future investigation.

Despite the diversity among the accessions in panicle form and weight, we did not find any relationship between lodging and panicle form. The lower visual lodging scores of accessions with semi-compact panicle forms can be explained by their positive association with lower panicle weight and shorter panicle length, which reduced grain yield. This result implies that increased panicle weight and length increase lodging. Although lodging in wheat can be increased by heavier ear weight [52], the effect is compensated by a heavier stem, which is strongly correlated with stem diameter and wall thickness. Our multiple linear regression analysis results show that greater panicle weight increased lodging. Similarly, in rice, a positive correlation of panicle weight with plant height has been reported [53], and heavier panicles have been shown to increase the bending moment of the basal internodes.

A negative relationship between lodging resistance and plant height has been reported in wheat, rice, and barley [13,52,54-56], and this observation has led to selection for shorter plants. In teff plants, the strong positive relationship between panicle length and panicle weight might be the main factor affecting the drag force and center of gravity of the plant, because in this study, genotypes with shorter panicles had lower lodging scores. However, the dwarf phenotypes, which tended to have very thin culms and high tiller numbers, were extremely susceptible to lodging. In rice, plant height is directly correlated with the plant's center of gravity, so in shorter plants the self-weight moment of the shoot is reduced. As a result, dwarf cultivars have higher lodging resistance than taller cultivars [57]. Thus, our results are contrary to findings in model crops such as wheat and rice, in which dwarf genotypes have superior lodging resistance because of their stiff, thick stems. A significant positive correlation between plant height and lodging score has also been reported in wheat [52]. However, an attempt to reduce the risk of lodging in wheat and oat through the introgression of extreme dwarfing genes such as $R h t 3$ and $D W-6$, respectively, failed because these genes are linked with deleterious traits. Extreme dwarf wheat cultivars accumulate less biomass and produce smaller seeds, which significantly decreases grain yield [58]. Similarly, poor extrusion of panicles from the flag leaf and lower seed numbers and size have been observed in extreme dwarf oat cultivars [59]. It is possible, therefore, that previous attempts to develop lodging-resistant teff cultivars by the introgression of dwarfing genes might have failed because of linkages between the dwarfing genes and thin, low-weight panicles, reducing grain yields. Unlike in other cereal crops, the panicle-peduncle length in teff is generally higher. It is longer in the very tall group than the improved cultivars while both have equivalent yielding potential. In addition, selection for a vertical distribution of the internodes such that they form a single straight axis has resulted in improved lodging resistance in barley and other cereal crops [60]. However, in our observations, the internodes interphase of most of the accessions showed deflection from the vertical axis, implying that the interphase point might be too weak to support the plant parts above it.

Stem diameter and internode wall thickness, particularly in the basal internodes, have been used as indicators of lodging resistance in major cereal crops [61]. Selection for increased stem diameter and wall thickness along with semi-dwarf phenotype have significantly increased the lodging resistance 
of modern wheat and rice cultivars. Stem diameter had a significant positive association with plant height, visual lodging score, base failure moment, and lodging index. In contrast to our results, previous studies in wheat have reported a negative correlation of stem diameter and wall thickness of different internodes with lodging scores [52,61]. Although significant differences in stem diameter were found among the genotypes in this study, a previous study of five teff genotypes found no significant difference in stem diameter among them [62]. This discrepancy is attributable mainly to the differences in the number of genotypes studied. The positive association between internode diameter and lodging resistance reported in previous studies of cereal crops was not seen in our study. The positive association between internode diameter and the visual lodging score in this study can be attributed mainly to the longer and heavier panicles in most of the accessions with wider internodes. Thus, the larger stem diameter in the tall teff accessions could not counterbalance the impact of a longer and heavier panicle. In this study, accessions showing better lodging resistance were associated not only with larger stem diameter and wall thickness, but also with lower tiller number per plant. This result implies that increasing the stem diameter alone would not necessarily increase lodging resistance in teff and should be integrated with increased stem strength or higher failure moment during selection for lodging resistance.

A modeling study of teff panicle bending when force was applied to the upper section of the plant [62] suggested that the bottom two internodes experience the highest stress. Similarly, other studies have shown that plant base strength-that is, the bending moment of the stem at the base of the plant-is closely related to lodging resistance [43]. These findings support our inference that base failure moment is a key parameter for lodging resistance in teff. We found significant differences in base failure moment among the accessions, and the positive association of base failure moment with plant height implies that the dwarf accessions had lower material strength than the tall accessions. Consistent with our result, the bending moment of most internodes in rice cultivars was significantly decreased in gibberellin-deficient and insensitive (dwarf) mutants, but increased in gibberellin-overproducing (tall) mutants [57]. In wheat and barley, however, greater base failure moment values in dwarf phenotypes than in tall phenotypes have been reported. These contradictory results might be due to morphological differences between wheat/barley and rice, because basal internode diameter and wall thickness are negatively correlated with plant height in wheat and barley. In addition, geometric factors such as the stem's dimensions and cross-sectional shape (i.e., the section modulus and the second moment of area) can influence how the stem can respond to a stress and, consequently, its behavior and properties.

\section{Conclusions}

This study demonstrates the presence of genotypic variation for agro-morphological traits and stem biomechanical properties. Although the study did not identify accessions that combine reduced plant height and lodging resistance, few accessions in the extreme tall group with good standing ability due to its higher base failure moment and pushing resistance with a reasonable yield potential were observed. These accessions can be used as a potential parental material in the breeding programs for increased lodging resistance. As part of the ongoing attempt to reduce the plant height of teff for lodging resistance without compromising the grain yield potential, selection for enhanced stem strength could be an alternative solution. Wider diameter, higher failure moment, and a lower tiller number along with reduced peduncle length might be worth considering as a selection criterion for lodging resistance breeding in teff. Our results suggest the need to pyramid genes for wider stem diameter, higher pushing resistance, and base failure moment, all of which correlate positively with plant height and lodging index, into dwarf or semi-dwarf accessions. Therefore, a strong crossing program is needed to evaluate the mode of inheritance of those traits and generate sufficient segregating populations.

Supplementary Materials: The following are available online at http://www.mdpi.com/2073-4395/10/7/1012/s1. Table S1: Mean squares of single environment ANOVA for agro-morphological traits and biomechanical properties of 320 teff germplasms. Table S2: Pearson correlation coefficient between eight agro-morphological traits and five biomechanical properties of 320 teff germplasms. 
Author Contributions: Conceptualization, M.B., N.H., G.A., and W.T.; data curation, M.B. and F.A.; validation, A.T. (Atsushi Tsunekawa), N.H., and M.T.; methodology, M.B., G.A., T.M., and T.I.; formal analysis, M.B.; investigation, M.B.; resources, A.T. (Atsushi Tsunekawa), E.A., N.H., and M.T.; writing-original draft preparation, M.B.; writing-review and editing, A.T. (Atsushi Tsunekawa), N.H., G.A., M.T., and E.A.; supervision, A.T. (Atsushi Tsunekawa), N.H., and G.A.; project administration, A.T. (Atsushi Tsunekawa), E.A., N.H., and A.T. (Asaminew Tassew); funding acquisition, A.T. (Atsushi Tsunekawa), N.H., and E.A. All authors have read and agreed to the published version of the manuscript.

Funding: This research was funded by the Science and Technology Research Partnership for Sustainable Development (SATREPS), Grant Number JPMJSA1601, Japan Science and Technology Agency (JST)/Japan International Cooperation Agency (JICA).

Acknowledgments: We extend our thanks to the members of the project management office, College of Agriculture and Environmental Sciences, of Bahir Dar University, and to Adet Agricultural Research Center and its staff, for coordinating the work and providing technical assistance. Special thanks to Amlaku Teshager and Atinkut Fentahun for their follow-up and technical assistance.

Conflicts of Interest: The authors declare no conflict of interest.

\section{References}

1. Mohammed, S.H.; Taye, H.; Sissay, T.A.; Larijani, B.; Esmaillzadeh, A. Teff consumption and anemia in pregnant Ethiopian women: A case-control study. Eur. J. Nutr. 2019, 58, 2011-2018. [CrossRef] [PubMed]

2. Jost, M.; Esfeld, K.; Burian, A.; Cannarozzi, G.; Chanyalew, S.; Kuhlemeier, C.; Assefa, K.; Tadele, Z. Semi-dwarfism and lodging tolerance in tef (Eragrostis tef) is linked to a mutation in the alpha-Tubulin 1 gene. J. Exp. Bot. 2015, 66, 933-944. [CrossRef] [PubMed]

3. Gebre, E.; Schlüter, U.; Hedden, P.; Kunert, K. Gibberellin biosynthesis inhibitors help control plant height for improving lodging resistance in E. tef (Eragrostis tef). J. Crop. Improv. 2012, 26, 375-388. [CrossRef]

4. Haregeweyn, N.; Tsunekawa, A.; Nyssen, J.; Poesen, J.; Tsubo, M.; Tsegaye Meshesha, D.; Schütt, B.; Adgo, E.; Tegegne, F. Soil erosion and conservation in Ethiopia. Prog. Phys. Geogr. Earth Environ. 2015, 39, 750-774. [CrossRef]

5. Costanza, S.; Dewet, J.; Harlan, J.R. Literature review and numerical taxonomy of Eragrostis tef (T'ef). Econ. Bot. 1979, 33, 413-424. [CrossRef]

6. Burtt-Davy, J. Teff (Eragrostis abyssinica). South. Afr. Agric. J. 1917, 5, 27-37.

7. D'Andrea, A.C. T'ef (Eragrostis tef) in ancient agricultural systems of highland Ethiopia. Econ. Bot. 2008, 62, 547-566. [CrossRef]

8. Ebba, T. T'EF (ERAGROST1S TBF) CULTIVARS: MORPHOLOGY and CLASSIFICATION; Addis Ababa University, College of Agriculture: Addis Ababa, Ethiopia, 1975.

9. Lee, H. Ethiopia Needs to Improve Production of Its Golden Crop Teff. Here's How. 2019. Available online: https://theconversation.com/ethiopia-needs-to-improve-production-of-its-golden-crop-teff-hereshow-112987 (accessed on 12 May 2020).

10. CSA. Agricultural Sample Survey: Report on Area and Production of Major Crops; Federal Democratic Republic of Ethiopia: Addis Ababa, Ethiopia, 2019.

11. Assefa, K.; Tefera, H.; Merker, A.; Kefyalew, T.; Hundera, F. Quantitative trait diversity in tef [Eragrostis tef (Zucc.) Trotter] germplasm from Central and Northern Ethiopia. Genet. Resour. Crop. Evol. 2001, 48, 53-61. [CrossRef]

12. Teklu, Y.; Tefera, H. Genetic improvement in grain yield potential and associated agronomic traits of tef (Eragrostis tef). Euphytica 2005, 141, 247-254. [CrossRef]

13. Pinthus, M.J. Lodging in Wheat, Barley, and Oats: The Phenomenon, its Causes, and Preventive Measures; Academic Press: Cambridge, MA, USA, 1974; pp. 209-263. [CrossRef]

14. Gebre, E.; Gugsa, L.; Schlüter, U.; Kunert, K. Transformation of tef (Eragrostis tef) by Agrobacterium through immature embryo regeneration system for inducing semi-dwarfism. South. Afr. J. Bot. 2013, 87, 9-17. [CrossRef]

15. Tadesse, D. Study on genetic variation of landraces of teff (Eragrostis tef (Zucc.) Trotter) in Ethiopia. Genet. Resour. Crop. Evol. 1993, 40, 101-104. [CrossRef]

16. Tefera, H.; Ketema, S. Production and Importance of Tef in Ethiopian Agriculture. In Proceedings of Narrowing the Rift: Proceedings of the International Workshop on Tef Genetics and Improvement; EARO: Addis Ababa, Ethiopia, 2001. 
17. Bennetzen, J.; Smith, S.; Yuan, Y.; Groth, D. Opening new avenues for the improvement of orphan crops in a time of rapid and potentially catastrophic change in worldwide agriculture. In Proceedings of the New approaches to plant breeding of orphan crops in Africa. Proceedings of an International Conference, Bern, Switzerland, 19-21 September 2007; pp. 11-19.

18. Chauhan, S.; Darvishzadeh, R.; Boschetti, M.; Nelson, A. Estimation of crop angle of inclination for lodged wheat using multi-sensor SAR data. Remote Sens. Environ. 2020, 236. [CrossRef]

19. Berry, P.M.; Sylvester-Bradley, R.; Berry, S. Ideotype design for lodging-resistant wheat. Euphytica 2006, 154, 165-179. [CrossRef]

20. Hirano, K.; Okuno, A.; Hobo, T.; Ordonio, R.; Shinozaki, Y.; Asano, K.; Kitano, H.; Matsuoka, M. Utilization of stiff culm trait of rice smos1 mutant for increased lodging resistance. PLoS ONE 2014, 9, e96009. [CrossRef] [PubMed]

21. Acreche, M.M.; Slafer, G.A. Lodging yield penalties as affected by breeding in Mediterranean wheats. Field Crop. Res. 2011, 122, 40-48. [CrossRef]

22. Wu, W.; Ma, B.-L.; Fan, J.-J.; Sun, M.; Yi, Y.; Guo, W.-S.; Voldeng, H.D. Management of nitrogen fertilization to balance reducing lodging risk and increasing yield and protein content in spring wheat. Field Crop. Res. 2019, 241. [CrossRef]

23. Corbin, J.L.; Orlowski, J.M.; Harrell, D.L.; Golden, B.R.; Falconer, L.; Krutz, L.J.; Gore, J.; Cox, M.S.; Walker, T.W. Nitrogen Strategy and Seeding Rate Affect Rice Lodging, Yield, and Economic Returns in the Midsouthern United States. Agron. J. 2016, 108, 1938-1943. [CrossRef]

24. Zhang, W.-J.; Li, G.-H.; Yang, Y.-M.; Li, Q.; Zhang, J.; Liu, J.-Y.; Wang, S.; Tang, S.; Ding, Y.-F. Effects of Nitrogen Application Rate and Ratio on Lodging Resistance of Super Rice with Different Genotypes. J. Integr. Agric. 2014, 13, 63-72. [CrossRef]

25. Ben-Zeev, S.; Rabinovitz, O.; Orlov-Levin, V.; Chen, A.; Graff, N.; Goldwasser, Y.; Saranga, Y. Less Is More: Lower Sowing Rate of Irrigated Tef (Eragrostis tef) Alters Plant Morphology and Reduces Lodging. Agronomy 2020, 10, 570. [CrossRef]

26. Miller, C.N.; Harper, A.L.; Trick, M.; Werner, P.; Waldron, K.; Bancroft, I. Elucidation of the genetic basis of variation for stem strength characteristics in bread wheat by Associative Transcriptomics. BMC Genom. 2016, 17, 500. [CrossRef]

27. Kelbert, A.; Spaner, D.; Briggs, K.; King, J. Screening for lodging resistance in spring wheat breeding programmes. Plant. Breed. 2004, 123, 349-354. [CrossRef]

28. Nomura, T.; Arakawa, N.; Yamamoto, T.; Ueda, T.; Adachi, S.; Yonemaru, J.I.; Abe, A.; Takagi, H.; Yokoyama, T.; Ookawa, T. Next generation long-culm rice with superior lodging resistance and high grain yield, Monster Rice 1. PLoS ONE 2019, 14, e0221424. [CrossRef] [PubMed]

29. Islam, M.S.; Peng, S.; Visperas, R.M.; Ereful, N.; Bhuiya, M.S.U.; Julfiquar, A.W. Lodging-related morphological traits of hybrid rice in a tropical irrigated ecosystem. Field Crop. Res. 2007, 101, 240-248. [CrossRef]

30. Chen, W.Y.; Liu, Z.M.; Deng, G.B.; Pan, Z.F.; Liang, J.J.; Zeng, X.Q.; Tashi, N.M.; Long, H.; Yu, M.Q. Genetic relationship between lodging and lodging components in barley (Hordeum vulgare) based on unconditional and conditional quantitative trait locus analyses. Genet. Mol. Res. 2014, 13, 1909-1925. [CrossRef] [PubMed]

31. Berry, P.M.; Sterling, M.; Spink, J.H.; Baker, C.J.; Sylvester-Bradley, R.; Mooney, S.J.; Tams, A.R.; Ennos, A.R. Understanding and Reducing Lodging in Cereals. In Advances in Agronomy; Academic Press: Cambridge, MA, USA, 2004; Volume 84, pp. 217-271. [CrossRef]

32. Berry, P.M.; Sterling, M.; Baker, C.J.; Spink, J.; Sparkes, D.L. A calibrated model of wheat lodging compared with field measurements. Agric. For. Meteorol. 2003, 119, 167-180. [CrossRef]

33. Sterling, M.; Baker, C.J.; Berry, P.M.; Wade, A. An experimental investigation of the lodging of wheat. Agric. For. Meteorol. 2003, 119, 149-165. [CrossRef]

34. Van Delden, S.H.; Vos, J.; Ennos, A.R.; Stomph, T.J. Analysing lodging of the panicle bearing cereal teff (Eragrostis tef). New Phytol. 2010, 186, 696-707. [CrossRef] [PubMed]

35. Spielmeyer, W.; Ellis, M.H.; Chandler, P.M. Semidwarf (sd-1), “green revolution” rice, contains a defective gibberellin 20-oxidase gene. Proc. Natl. Acad. Sci. USA 2002, 99, 9043-9048. [CrossRef]

36. Fischer, R.; Stockman, Y. Increased kernel number in Norin 10-derived dwarf wheat: Evaluation of the cause. Funct. Plant. Biol. Aust. J. Plant. Physiol. 1986, 13, 767-784. [CrossRef]

37. Evenson, R.E.; Gollin, D. Assessing the impact of the green revolution, 1960 to 2000. Science 2003, 300, 758-762. [CrossRef] 
38. Assefa, K.; Yu, J.K.; Zeid, M.; Belay, G.; Tefera, H.; Sorrells, M.E. Breeding tef [Eragrostis tef (Zucc.) trotter]: Conventional and molecular approaches. Plant. Breed. 2011, 130, 1-9. [CrossRef]

39. Tadele, Z. Orphan crops: Their importance and the urgency of improvement. Planta 2019, 250, 677-694. [CrossRef] [PubMed]

40. Smith, S.M.; Yuan, Y.; Doust, A.N.; Bennetzen, J.L. Haplotype Analysis and Linkage Disequilibrium at Five Loci in Eragrostis tef. G3 (Bethesda) 2012, 2, 407-419. [CrossRef] [PubMed]

41. Wu, W.; Shah, F.; Duncan, R.W.; Ma, B.L. Grain yield, root growth habit and lodging of eight oilseed rape genotypes in response to a short period of heat stress during flowering. Agric. For. Meteorol. 2020, 287. [CrossRef]

42. Crook, M.J.; Ennos, A.R. Stem and root characteristics associated with lodging resistance in four winter wheat cultivars. J. Agric. Sci. 1994, 123, 167-174. [CrossRef]

43. Baker, C.; Berry, P.; Spink, J.; Sylvester-Bradley, R.; Griffin, J.; Scott, R.; Clare, R. A method for the assessment of the risk of wheat lodging. J. Theor. Biol. 1998, 194, 587-603. [CrossRef]

44. Wu, W.; Ma, B.-L. Assessment of canola crop lodging under elevated temperatures for adaptation to climate change. Agric. For. Meteorol. 2018, 248, 329-338. [CrossRef]

45. Caldicott, J.; NUTTALL, A. A method for the assessment of lodging in cereal crops. J. Natl. Inst. Agric. Bot. 1979, 15, 88-91.

46. Wu, W.; Huang, J.; Cui, K.; Nie, L.; Wang, Q.; Yang, F.; Shah, F.; Yao, F.; Peng, S. Sheath blight reduces stem breaking resistance and increases lodging susceptibility of rice plants. Field Crop. Res. 2012, 128, 101-108. [CrossRef]

47. Wu, W.; Ma, B.L. A new method for assessing plant lodging and the impact of management options on lodging in canola crop production. Sci. Rep. 2016, 6, 31890. [CrossRef]

48. Hai, L.; Guo, H.; Xiao, S.; Jiang, G.; Zhang, X.; Yan, C.; Xin, Z.; Jia, J. Quantitative trait loci (QTL) of stem strength and related traits in a doubled-haploid population of wheat (Triticum aestivum L.). Euphytica 2005, 141, 1-9. [CrossRef]

49. Kashiwagi, T.; Ishimaru, K. Identification and functional analysis of a locus for improvement of lodging resistance in rice. Plant. Physiol. 2004, 134, 676-683. [CrossRef] [PubMed]

50. Crook, M.; Ennos, A. Mechanical differences between free-standing and supported wheat plants, Triticum aestivum L. Ann. Bot. 1996, 77, 197-202. [CrossRef]

51. SAS. The SAS System for Windows ver. 9.0; SAS Institute: Cary, NC, USA, 2005.

52. Zuber, U.; Winzeler, H.; Messmer, M.; Keller, M.; Keller, B.; Schmid, J.; Stamp, P. Morphological traits associated with lodging resistance of spring wheat (Triticum aestivum L.). J. Agron. Crop. Sci. 1999, 182, 17-24. [CrossRef]

53. Ma, J.; Ma, W.; Tian, Y.; Yang, J.; Zhou, K.; Zhu, Q. The culm lodging resistance of heavy panicle type of rice. Zuo Wu Xue Bao 2004, 30, 143-148.

54. Navabi, A.; Iqbal, M.; Strenzke, K.; Spaner, D. The relationship between lodging and plant height in a diverse wheat population. Can. J. Plant. Sci. 2006, 86, 723-726. [CrossRef]

55. Stanca, A.; Jenkins, G.; Hanson, P. Varietal responses in spring barley to natural and artificial lodging and to a growth regulator. J. Agric. Sci. 1979, 93, 449-457. [CrossRef]

56. Zhang, W.; Wu, L.; Wu, X.; Ding, Y.; Li, G.; Li, J.; Weng, F.; Liu, Z.; Tang, S.; Ding, C.; et al. Lodging Resistance of Japonica Rice (Oryza Sativa, L.): Morphological and Anatomical Traits due to top-Dressing Nitrogen Application Rates. Rice (N. Y.) 2016, 9, 31. [CrossRef]

57. Okuno, A.; Hirano, K.; Asano, K.; Takase, W.; Masuda, R.; Morinaka, Y.; Ueguchi-Tanaka, M.; Kitano, H.; Matsuoka, M. New Approach to Increasing Rice Lodging Resistance and Biomass Yield Through the Use of High Gibberellin Producing Varieties. PLoS ONE 2014, 9, e86870. [CrossRef]

58. Flintham, J.; Börner, A.; Worland, A.; Gale, M. Optimizing wheat grain yield: Effects of Rht (gibberellininsensitive) dwarfing genes. J. Agric. Sci. 1997, 128, 11-25. [CrossRef]

59. Milach, S.; Federizzi, L. Dwarfing genes in plant improvement. Adv. Agron. 2001, 73, 35-63.

60. Madić, M.; Knežević, D.; Paunović, A.; Đurović, D. Plant height and internode length as components of lodging resistance in barley. Acta Agric. Serbica 2016, 21, 99-106. [CrossRef] 
61. Tripathi, S.C.; Sayre, K.D.; Kaul, J.N.; Narang, R.S. Growth and morphology of spring wheat (Triticum aestivum L.) culms and their association with lodging: Effects of genotypes, $\mathrm{N}$ levels and ethephon. Field Crop. Res. 2003, 84, 271-290. [CrossRef]

62. Blosch, R.; Plaza-Wuthrich, S.; Barbier de Reuille, P.; Weichert, A.; Routier-Kierzkowska, A.L.; Cannarozzi, G.; Robinson, S.; Tadele, Z. Panicle Angle is an Important Factor in Tef Lodging Tolerance. Front. Plant. Sci. 2020, 11, 61. [CrossRef]

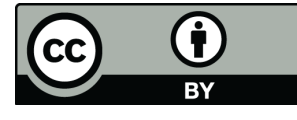

(C) 2020 by the authors. Licensee MDPI, Basel, Switzerland. This article is an open access article distributed under the terms and conditions of the Creative Commons Attribution (CC BY) license (http://creativecommons.org/licenses/by/4.0/). 